TANULMÁNYOK 2019/1. Bölcsészettudományi Kar, Újvidék

STUDIJE 2019/1. Filozofski fakultet, Novi Sad

STUDIES 2019/1. Faculty of Philosophy, Novi Sad

ETO: 304.42PRNJAT B.

ORIGINAL SCIENTIFIC PAPER

DOI: $10.19090 / \mathrm{tm} .2019 .1 .139-146$

A kézirat leadásának időpontja: 2019. február 25.

Az elfogadás időpontja: 2019. május 3.

TÓTH GLEMBA Klára

Tartományi Felsőoktatási és Tudományos Kutatási Titkárság

klara.glemba@gmail.com

\title{
A KULTURÁliS POLITIKA AZ ÁlLAMHATALOM ÉS A SZABADSÁG HATÁRÁN BRANKO PRNJAT ${ }^{78}$ MÚVEIBEN
}

\section{Kulturna politika kao moć države i granice slobode u delima Branka Prnjata}

\section{Cultural Policy Between State Power and Freedom in the Works of Branko Prnjat}

\begin{abstract}
A kulturális politika a tudat ébredése az új értékek szükségességéröl.
(Branko Prnjat)
\end{abstract}

A kulturális politika nem új keletű fogalom, felismerhető az időszámításunk előtti időszakban is, majd végigkísérhető a történelem folyamán egészen napjainkig. Kutatásának szükségességét és időszerűségét alátámasztja a kulturális életben mind jobban megnövekedett szereplők és jelenségek száma, amelyek állandó kihívásként hatnak a témát kutatókra. Branko Prnjat, a kulturális politika szerbiai úttörője nemcsak felismerte a fogalommal való foglalkozás szükségességet és indokoltságát, hanem megalapozta az egyetemi szinten való oktatását is. Általa jutott a kulturális politika olyan magas szintre, amely manapság mint tudatébredést definiálja, magába foglalja nemcsak az új értékek feltárását, hanem útmutató is egyben ezekhez az értékekhez. A többkultúrájú (multikulturális) közösség - amely ugyanakkor többnyelvű

\footnotetext{
${ }^{78}$ Dr. Branko Prnjat nyugalmazott egyetemi tanár a belgrádi Politikai Tudományok Karán a kultúrpolitika és a kultúrszociológia tárgyakat tanította. Nevéhez füződik a kulturális politika tantárgy, majd később a szakirány bevezetése is, jelentőséget adva ezzel is a kultúra, valamint a kulturális politika területén elért kutatásainak. A posztgraduális és a specializációs képzések is az ő irányításával folytak. Később az újságíróképzés és a politikai szociológia tanszékvezető tanára lett. A belgrádi Művészeti Akadémián kulturológiát is tanított. Tanulmányait többnyire szerb nyelven írta, ezért ez a nyelvterület tudta teljes egészében megismerni az általa megfogalmazott tudományos felismeréseket, de műveit lefordították angolra, németre, franciára, spanyolra, olaszra, oroszra, portugálra, arabra és magyar nyelvre is.
} 
közösség is - teljes kibontakozása, identitásának megvalósulása csakis az államhatalom által gyakorolt kulturális politika egyenrangú alkalmazása, a kultúrák kölcsönös tiszteletben tartása alapján történhet meg.

Kulcsszavak: kulturális politika, államhatalom, multikulturalitás, identitás, társadalom

Témaválasztásomat az indokolta, hogy összhangban a konferencia ${ }^{79}$ témakörével, a más nyelvü (többségi nyelven) megírt kutatási eredményeket feltárjam egy olyan témakör kapcsán, amely szinte minden pontján találkozik a nyelvekkel. Jóllehet a Branko Prnjat által megalapozott és továbbfejlesztett kulturális politika szakirány számos szakembert, majd tudományos fokozattal rendelkező, a kulturális politikában jártas kutatót készített fel, kevés tudományos eredmény került át a magyar nyelvterületre. A kulturális politika meghatározott irányvonalai és tudományos eredményei megismerésének és alkalmazásának hiánya mély ürt hagy maga után a kulturális életben, rosszabb esetben pedig még hátráltatja is a többnyelvü, kisebbségi helyzetben élő közösség kulturális életét, mintsem elősegítené fejlődését.

A kisebbségi helyzetben élő, kulturális politikával foglalkozó kétnyelvü, a többség nyelvét jól beszélő kutatók számára fontos szerepet játszanak a többség nyelvén megjelent tanulmányok, segítségükkel olyan tapasztalatokat tudnak szerezni, kutatási eredményeket megismerni, amelyeket könnyüszerrel átvihetnek a saját kisebbségi területükre is. A kétnyelvüség révén ilyen módon előnyt szereznek az új tudományos felismerések megosztásában. Ez történik a mi esetünkben is, amikor a kulturális politika kiemelkedő szakértőjéről, annak tudományos munkásságáról értekezünk. Nem ez az első eset, hogy magyar nyelven olvashatjuk Branko Prnjat müveit. A Létünk folyóirat 1981-ben A kulturális élet monopolizmusa címmel közölte Branko Prnjat Kulturna politika című könyvéből egy hosszabb tanulmány fordítását, amellyel a többség nyelvén megjelent müvek alapján, a magyar nyelvterületen is kezdetét veszi a kulturális politikával való foglalkozás. Már ebben a tanulmányban is körvonalazódik Prnjatnak a szabadságra vonatkozó felismerése, különös tekintettel az álszükségletekre (reklámokra), amelyek sajátos (a szabadsággal ellentétben álló) diktatúrával befolyásolják az ember viselkedését, veszélyeztetve ezzel az autentikus kulturális szükségletek kialakulását (Prnjat 1981, 174). Sajnos, a magyar nyelvterületre nem jutott el más tanulmány, így a kulturális politikával való megismerkedést, foglalkozást csakis a szerb nyelv közvetítette. Ugyanakkor ez az első tanulmány, amely magyar nyelven értekezik Prnjatnak az alkotás szabadságáról szóló elméletéről.

\footnotetext{
${ }^{79}$ A tanulmány 2018. november 6-án, a Nyelvek mezsgyéjén - a két- és többnyelvűség interdiszciplináris megközelítése - nemzetközi tudományos konferencián hangzott el, a 26. Egyetemi Nyelvészeti Napok keretén belül.
} 
Branko Prnjat műveinek központi témája a szabad ember, az alkotás szabadsága, az egyén alkotói kiteljesülése, a kulturális szükségletek fejlődése, a kultúra demokratizálódása, valamint az a kulturális politika, amellyel az állam a művészet szabad kibontakozását és az új értékek megteremtését segíti. Szerinte a kulturális politika a kulturális fejlődés feltételeit és lehetőségeit határozza meg (Ljubojev 1995, 43). Prnjat a kulturális politikát a humanizmus és emancipáció szemszögéből kutatja, amelyekben a kulturális szükségletek szabad fejlődését látja (Mitrović 2008, 14). A teoretikus Prnjat szemlélete A politikai kultúra enciklopédiájában is helyet kapott, amelyben a fogalom meghatározását, fejlödését, valamint a kulturális politika modelljeinek körvonalazását $\mathrm{s}$ a kultúra demokratikus jellegét hangsúlyozza (Prnjat 1993, 885-888).

Amikor a kulturális politikáról beszélünk, mindig a társadalom életbevágó fejlödési fázisaira gondolunk, arra a stratégiára, amely a szellemi és az anyagi megújhodást eredményezi (Prnjat 2012, 6). A kulturális politika időbeli elhelyezése, felismerése, valamint a demokratikus állam tevékenységének meghatározása jelentette azt a kiindulópontot, amelyről Branko Prnjat kutatásaiban elindult. A korábban megjelent müveiben (Kulturna politika i kulturni razvoj: Uvod u kulturnu politiku) már világosan felismerhető volt a szerző azon törekvése, hogy a kulturális politika céljaként az alkotás szabadságát tűzze ki. Meghatározásaiban a müvészetek, alkotások szabadságát az alapvető jogok közé sorolta, és ezentúl csakis így szemlélte a kulturális politikát.

Azzal a céllal, hogy a kulturális politika eltávolodjon a represszív és destruktív politikától (amire a történelem során tapasztalt számos példa is utal: könyvégetés, az alkotók üldözése stb.), Prnjat még a terminológiai változás lehetöségét is felveti, és a kultúra politikája meghatározást fontolgatja (Prnjat $2006,47)$. Ana Birešev véleménye szerint, ha ragaszkodunk a kulturális politika fogalmához, akkor a fogalom alatt a kulturális életnek csak azon tevékenységei értendők, amelyek kulturális fejlődést, alkotótevékenységet, szabadságot és önállóságot eredményeznek (Birešev 2006, 189). Stevan Majstorović úgy látja, hogy a kulturális politikát az állam kettős funkciója befolyásolja: egyidejűleg ösztönzi és fékezi is az alkotók szabadságát (Majstorović 1997, 219). Mindenesetre a kulturális politika fogalom meghatározásáért szállnak síkra Milena DragičevićŠešić és Branimir Stojković is, amikor a kulturális politika fogalmát a politika fogalmával összefüggésben taglalják. Ennek értelmében, ha a politika tudatos tevékenység, társadalmilag hasznos és elismerhető célok érdekében, amelyből következően beszélhetünk gazdasági, egészségügyi és oktatási politikáról is, akkor a kultúra ilyen szempontból való megközelítését is szabadon nevezhetjük kulturális politikának (Dragičević-Šešić-Stojković 2003, 36). 
Branimir Stojković tovább elemzi a kulturális politikát, és megállapítja, hogy annyi kulturális politika van, ahány állam, így több modell is kirajzolódik: a liberális, állami bürokratikus-felvilágosodási, állami presztízs és felvilágosodási, nemzeti emancipációs, regionális-nyelvi és etnikai modell (Stojković 1993, 36). Szerinte minden társadalomnak szüksége van olyan sajátos kulturális politikára, amely a kulturális tevékenységekhez kötődik, mint pl. a színházi vagy a könyvtári kulturális politika stb. (Stojković 1995, 36).

Továbbgondolva az itt felvetett elképzelést, a kisebbségekkel szembeni sajátos kulturális politika (a törvényhozás területén, a kisebbségek kulturális intézményeinek, humán erőforrásának biztosítása területén stb.) hozná meg azt a szabadságot a kultúrában, amelyet Prnjat a müveiben boncolgat.

Történelmi visszatekintéseiben Prnjat a kulturális politika alapjait a hellenizmus koráig vezeti vissza (mint pl. Werner Jeager), valamint a Krisztus előtti időszakra, amelyről nagyon keveset tudunk, de szerinte Jeager felismerte a zsarnokoskodás folytonosságát és szabályszerüségét, amelyek állandó ismétléséből a kulturális politika kezdete figyelhető meg (Prnjat 2006, 35). Periklész (i. e. 500-429) elméletéből megismerhetjük az állam szerepét, szerinte az állam feladata az általános müveltség megszerzésének díjmentes biztosítása. Periklész nevéhez füződik a theorikon, amely a szegényebb rétegek számára a színházi helyek megvásárlását jelentette. Szerinte minden kulturális politika, ami az emberi élethez kötődik (Prnjat 2006, 38). Prnjat az ógörög filozófusok müveiben is felfedezte a kulturális politika alapjait. Platón (az Állam és a Törvények) felismeri az alkotás és a müvészet közönségre gyakorolt spontán hatásának fontosságát és szerepét a társadalomban, de ugyanakkor azt az állam az általa meghatározott szabályok alá rendelné, nevelői és oktatói szereppel ruházná fel, a cenzúra szerepét hangsúlyozva, az ellenkezők tevékenységét pedig betiltaná (Prnjat 2006, 8).

Prnjat értekezéseire messzemenőleg Platónnak a művészet és az állam kapcsolatáról szóló tanítása volt a legnagyobb hatással. Nyomon követi Platón azon álláspontját, amely szerint a művészetekről mint küldetésről beszél, valamint a művészi alkotások szükséges átértékeléséröl (Prnjat 1999, 259). Az ógörög filozófusok közül Prnjatot még Arisztotelész zeneelmélete foglalkoztatja, amelyben úgyszintén az alkotás szabadságát véli felismerni.

A Politika címü müvében Arisztotelész a zene meghatározása révén ismeri fel az alkotás szabadságát, és azt állítja, hogy a zeneművészet az emberi 
lélek etikai jellemzője, véleményt a zenéről is csak az mondhat, aki megismeri, a megismeréshez pedig szükséges az állam által létrehozott oktatási rendszer, ami nem más, mint a kulturális politika (Prnjat 2006, 26).

Branko Prnjat a görög filozófusoktól továbblépve John Milton (Areopagitica) művében is fellelte a szabadságra vonatkozó eszméket. John Milton az emberi jogok, a szabad vallásgyakorlás szószólója volt, az írott sajtó szabadságáról szólva a cenzúra ellen emelte fel a hangját. Az irodalmárt az angol parlament által jóváhagyott cenzor szerepe és feladata késztette arra, hogy rámutasson, a cenzúra nemcsak a tudomány, hanem az igazság kibontakozását is elértékteleníti (Prnjat 2006, 26). Prnjat szerint Milton műveinek legkiválóbb adaléka a cenzúra bírálata.

Milton a cenzor és az alkotó kapcsolatát elemezve arra a következtetésre jutott, hogy a cenzor, aki politikailag felülbírál egy müvet, csakis olyan személy lehet, aki állandóan azt olvassa, amit mások alig tudnak elolvasni: ezért a jövőben ezt a szerepet csakis a tudatlanok, a megalkuvók és a gyengék tölthetik be (Prnjat 2006, 31). Ezzel ellentétben állnak az alkotók, akik a tudományt önmagukért szeretik, és az emberiség hasznára válnak. John Milton álláspontja még ma is időszerű a cenzúra ellenzői körében, a francia forradalmárok az emberi jogok és a szólásszabadság kapcsán is John Miltontól merítették az ötletet (Prnjat 2006, 34).

A második világháború utáni politikai viszonyok nyomot hagytak a társadalmi élet minden területén. Meglátszott ez a kulturális politikán is, különösen az akkor érvényben levő kulturális politika állami modelljén.

A politika és a művészet viszonya ebben az időszakban különösen alakult: a müvészeti alkotás helyzetét és szabadságát az aktuális politika határozta meg (Prnjat 2012, 7). Prnjat felismerése szerint csak az ötvenes évek hoztak eredményt ezen a téren, azt a látszatot keltve, hogy az állam lehetőséget ad a demokratikus és a szabad alkotók megnyilvánulásának (Prnjat 2012, 7). Azonban csak egy új kulturális politika körvonalazódott, mégpedig a külpolitika területén; nemzetközi színházi és filmfesztiválokat alapítottak a fővárosban, amelyek révén a hazai publikum első kézből szerezhetett tudomást a világ legújabb alkotásairól, de a belső művészi szabadság kibontakozása nem jutott kifejezésre (Prnjat 2012,7). Amennyire toleráns volt a kulturális politika a külpolitika irányában, annyira nem kedvelte a belső művészi szabadság kibontakozását, hiányzott a már meglevő művészi hagyaték iránti szenzibilitás, az alkotás szabadsága, amely a demokratikus társadalom kulturális politikájának alappillére (Prnjat 2012, 8). 
Mindezeket összegezve Prnjat a demokratikus kulturális politikáért száll síkra, előtérbe helyezi az alkotás, a gondolat és a kommunikáció szabadságát. Számos tanulmányában a jövő felé fordul, és nagy hangsúlyt helyez a fiatalok alkotóerejére. Mindez azért fontos, mert a kultúra egy állam kulturális identitásának legrangosabb, leglátványosabb bemutatkozási formája (Prnjat 1986, 24).

Gondolatait továbbfüzve megállapítja, hogy a modern korban a kultúra a piacgazdálkodás törvényei közepette fejlödik és alakul, amelyben a cél csupán a profit megszerzése, nem pedig a kulturális értékek bemutatása.

A piacorientált kultúra pedig már nem a kultúra terjesztését segíti, hanem a profitra helyezi a hangsúlyt, ezért vele kapcsolatban már nem is lehet szabadságról beszélni. Segédeszközként jelenik meg a reklám, amely a fiktív szükségletek kialakítása, melyek fokozatosan és közvetlenül behálózzák az embert, anélkül, hogy tudatában lenne e folyamatnak, a mesterséges szükségletek favorizálásával pedig az autentikus kulturális szükségleteket fojtják el (Prnjat 1981, 174).

Az új társadalmi, gazdasági és politikai kihívások új kulturális politikát igényelnek. Ennek hiányát ismerte fel Prnjat; a Politika napilap hasábjain értekezve arra a következtetésre jutott, hogy a kulturális politika állami modellje a társadalmi élet peremére szorulva képtelen lépést tartani a kultúra természetes és ösztönző tényezőivel (Prnjat 2018, 18).

A kulturális politikával mint jelenséggel való foglalkozás egyik legteljesebb, legátfogóbb meghatározását kínálta fel Branko Prnjat, amikor a filmmüvészetről és a tömegkulturális eszközökről értekezett, amelyben a kulturális fejlődés és alkotás a meglevő társadalmi viszonyok összehangolásában mutatkozik meg (Ljubojev 1995, 43).

A kulturális politika azonban a politika új kutatási területeként nincs kellőképpen tudományosan kidolgozva (Prnjat 2006, 49). Hiánya, valamint a kulturális élet marginalizálása pedig a társadalmi élet más területeire is kihat. A legkívánatosabb társadalmi fejlödés az, amelyben a kultúra (tehát a művészet is) természetes, ösztönző komponens (Prnjat 2012, 8), amelyben kibontakozhat az egyén alkotói és kulturális értékek utáni vágya (Prnjat 1981, 171).

Prnjat elemzéseivel a kultúra visszakerült a társadalom vérkeringésébe (Sretenović 2007, 22), hangsúlyozva annak demokratikus jellegét. 


\section{Összefoglaló}

Tanulmányomban a Branko Prnjat által meghatározott kulturális politikát az államhatalom és az alkotás szabadságának tükrében vizsgáltam. Tettem ezt annak érdekében, hogy a szerb nyelven megjelent tanulmányok, elemzések eredményeit közelebb hozzam a magyar nyelvterületen élő és alkotó kutatók számára. Az elemzés kiterjedt a Prnjat által megfogalmazott érvelésekre, valamint olyan kutatók álláspontjainak ismertetésére, akik behatóan foglalkoznak ezzel a témakörrel. Jóllehet a kulturális politika nem új keletü fogalom, a terület nincs kellöképpen tudományosan feldolgozva olyan értelemben, amely a kulturális életet visszahozná a társadalom vérkeringésébe. A kulturális politika állami modellje már nem alkalmazható a mai modern világban. Hogy lépést tartson az új társadalmi, gazdasági és politikai kihívásokkal, a demokratikus államban olyan kulturális politikára van szükség, amelyben kibontakozhat az alkotás és a fejlődés szabadsága. A szerb nyelvterületen a kulturális politika témakörről megjelent kutatási eredmények és tanulmányok folyamatos és rendszerezett magyar nyelvű fordítása és feldolgozása, majd annak publikálása még várat magára. A kulturális politika kutatói számára ez még egy jövőbeni kihívást jelenthet.

\section{Kiadások}

Prnjat, Branko. 1981. A kulturális élet monopolizmusa. Létünk 11 (1): 170-188.

http://adattar.vmmi.org/cikkek/2347/letunk_1981.1_13_branko_prnjat.pdf (2018. aug. 31.) Prnjat, Branko. 1986. Kulturna politika i kulturni razvoj. Beograd: Savremena administracija. Prnjat, Branko. 1999. Politička valorizacija umetnosti. Zbornik radova fakulteta dramskih umetnosti (3): 259-263.

Prnjat, Branko. 2006. Uvod u kulturnu politiku. Novi Sad: Stylos.

Prnjat, Branko. 2012. Politika i umetnost. Kultura i društveni razvoj 3-8.

Prnjat, Branko. 2018. Kultura bez kulturne politike. Politika febr. 24. 18.

\section{Irodalom}

Birešev, Ana. 2006. Kulturna politika u teoriji: Kultura. I Čitanje muzike; II Kulturna politika. 116-117. Beograd: Zavod za proučavanje kulturnog razvitka.

Dragičević-Šešić, Milena-Stojković, Branimir. 2003. Kultura-menadžment, animacija, marketing, Beograd: Clio.

Ljubojev, Petar. 1995. Evropski film i društveno nasilje. Novi Sad-Beograd: Matica srpska-Prosveta.

Majstorović, Stevan. 1997. Kultura i demokratija. Beograd: Prosveta. 
Tóth Glemba Klára: A kulturális politika az államhatalom és a szabadság...

Mitrović R., Ljubiša. 2008. Između kulture zavisnosti i traganja za sopstvenim modelom 1: Nova srpska misao: Kulturna politika u Srbiji (1): 7-27.

Prnjat, Branko et al. 1993. Enciklopedija političke kulture. 885-888. Beograd: Savremena administracija.

Sretenović, Mirjana. 2007. Na mrtvoj straži. Politika máj. 12. 22.

Stojković, Branimir. 1993. Evropski kulturni identitet. Niš: Prosveta.

Klara TOT GLEMBA

\section{KULTURNA POLITIKA KAO MOĆ DRŽAVE I GRANICE SLOBODE U DELIMA BRANKA PRNJATA}

Kulturna politika nije moderan pojam, prisutna je tokom čitave naše istorije, kako pre naše ere, tako do današnjeg dana. Sve više učesnika i aktivnosti na polju kulture i kulturnog stvaralaštva motiviše istraživača da se uvek iznova bavi definisanjem ovog pojma. Jedan od najznačajnijih teoretičara, utemeljivača kulturne politike na ovim prostorima Branko Prnjat, ne samo što je prepoznao nužnost i opravdanost bavljenja istraživanjem pojma, nego je u mnogome doprineo da se predmeti kao što su sociologija kulture i kulturna politika nađu među nastavnim predmetima, na postdiplomskim studijama na fakultetima širom Srbije. Zahvaljujući njemu, kulturna politika je postigla onaj nivo istraživanja, na kojem se prilikom definisanja pojma, prepoznaje buđenje svesti kako prema pronalaženju novih kulturnih vrednosti tako i u davanja putokaza do njih. Ispoljavanje, ostvarenje i razvoj identiteta multikulturnih društava, koja su istovremeno i višejezična društva moguće je jedino od države prihvaćene i podržane kulturne politike koja se ostvaruje u uzajamnom poštovanju i uvažavanju kultura. Ključne reči: kulturna politika, državna moć, multikulturalizam, identitet, društvo

\section{Klára TÓTH GLEMBA}

\section{CULTURAL POLICY BETWEEN STATE POWER AND FREEDOM IN THE WORKS OF BRANKO PRNJAT}

Cultural policy is not a novel concept, it existed long before before our time and its development can be traced through history until today. The increasing number of social actors and phenomena in cultural life today justifies the need for research in this area and also presents a constant challenge for researchers. Branko Prnjat is the Serbian pioneer in cultural policy, the first not only to recognize the significance of exploring the concept of cultural policy but also to lay the foundations for teaching cultural policy at university level. Prnjat is also responsible for the definition of cultural policy in terms of awakening, which includes not only recognizing new values but also reaching them. A multicultural community, which is at the same time also a multilingual community, can only flourish and its identity can only be forged if cultural policy is equally exercised by the state power, if there is mutual respect for cultures.

Keywords: cultural policy, state power, multiculturalism, identity, society 